University of Nebraska - Lincoln

DigitalCommons@University of Nebraska - Lincoln

Effects of Food Attributes and Feeding Environment on Acceptance, Consumption and Body Weight: Lessons Learned in a Twenty-Year Program of Military Ration Research

\author{
Edward S. Hirsch \\ US Army Natick Soldier Center, Natick, MA \\ F. Matthew Kramer \\ US Army Natick Soldier Center, Natick, MA \\ Herbert L. Meiselman \\ US Army Natick Soldier Center, Natick, MA
}

Follow this and additional works at: https://digitalcommons.unl.edu/usarmyresearch

Part of the Operations Research, Systems Engineering and Industrial Engineering Commons

Hirsch, Edward S.; Kramer, F. Matthew; and Meiselman, Herbert L., "Effects of Food Attributes and Feeding Environment on Acceptance, Consumption and Body Weight: Lessons Learned in a Twenty-Year Program of Military Ration Research" (2005). US Army Research. 35.

https://digitalcommons.unl.edu/usarmyresearch/35

This Article is brought to you for free and open access by the U.S. Department of Defense at DigitalCommons@University of Nebraska - Lincoln. It has been accepted for inclusion in US Army Research by an authorized administrator of DigitalCommons@University of Nebraska - Lincoln. 


\title{
Effects of food attributes and feeding environment on acceptance, consumption and body weight: lessons learned in a twenty-year program of military ration research US Army Research (Part 2)
}

\author{
Edward S. Hirsch*, F. Matthew Kramer, Herbert L. Meiselman \\ US Army Natick Soldier Center, Natick, MA 01760-5020, USA
}

Received 7 July 2003; revised 1 April 2004; accepted 10 April 2004

\begin{abstract}
Twenty years of testing in the field has consistently revealed that food intake is inadequate when packaged military rations are fed as the sole source of food. Food intake is much lower and there is a loss of body weight. Conversely when these rations are fed to students or military personnel for periods ranging from 3 to 42 days in a cafeteria-like setting, food intake is comparable to levels of a control group provided with freshly prepared food. Under these conditions, body weight is maintained. In this review, the consumption pattern is considered in terms of characteristics of the food (acceptability, variety, portion size, beverages, serving temperature, appropriateness for time of day, monotony, and novelty) and the eating milieu (social interactions, time, ease of preparing and consuming a meal). The twentyyear program of military ration research has led us to conclude that both the food and the context must be considered in understanding and controlling food intake.
\end{abstract}

Published by Elsevier Ltd.

Keywords: Military rations; Food intake; Food acceptance; Monotony; Novelty; Portion size; Feeding environment

\section{Introduction}

In the late 1970s military planners who were in the process of phasing out the use of canned military rations asked the Natick ration designers to consider a new scenario for feeding soldiers in the field. They envisioned a new ration, called the Meal, Ready-to-Eat (MRE), packed in flexible plastic retort pouches with some freeze-dried components, as a significant improvement. The military planners asked Natick whether the new rations would sustain soldiers for periods of time as long as a month or so. Natick researchers translated this query into several research questions, which dominated our work for the next decade or more: 1 . How much will soldiers eat of this packaged food under field conditions? 2. What will happen to food intake and body weight over time? 3 . How long can

\footnotetext{
* Corresponding author.

E-mail address: edward.hirsch@natick.army.mil (E.S. Hirsch).
}

this ration be fed as the sole source of food? 4 . Will people eat enough to sustain good health and performance, and how would you determine that?

The answers to these questions forced us to change our view of what factors control food intake. In the process of conducting these ration studies we learned several important things. First, our initial emphasis on the characteristics of the food and its acceptability had to be balanced with many other non-food factors that exert important influences on intake. Second, we came to question whether variables that had powerful effects on human food intake in short-term laboratory studies exerted similar effects on long-term intake. Third, we believe that these concerns could readily be extended to another 'real world' feeding problem, the obesity epidemic, where laboratory findings have yet to find a way to exert a demonstrable influence on this everexpanding problem (Mokdad et al., 2001). In the remainder of this paper we review the work that led us to these conclusions. 
The original meal ration or MRE was composed of 30 food items, two beverages, a cream substitute, assorted candies and a gravy base, organized into 12 menus with the repetition of some items other than entrees. Each meal can be eaten hot or cold, and typically contains an entrée (main dish), a starch or a vegetable, crackers and a spread, a beverage powder to add to water and a sweet dessert item. Water is generally available but is at ambient temperature and may require some effort to obtain and extra effort to heat or chill. Three meals provide $3600 \mathrm{kcal}$ per day, as recommended by the Surgeon General for active young male soldiers. These military rations have a number of significant constraints, when compared to conventional foods. They are required to have a shelf-life of 3 years, and consequently have substantial protective packaging. All ration components must be fully pre-cooked, and be capable of being consumed at ambient temperature. They are multicomponent, and each ration component is separately packaged and can be separately consumed.

In an effort to reduce the manpower and logistics burden of operating a field feeding system, the planners wanted to use this new ration as the sole source of food for as long as practical without compromising the health and effectiveness of military personnel. Other plans for feeding soldiers in the field called for minimal use of packaged rations with the gradual introduction of fresh foods. Further, there were undocumented reports from the field which claimed that troops subsisting on similar rations for extended periods of time experienced gastrointestinal difficulties. Both constipation and diarrhea were reported but not fully documented.

In the 1970s, the variables that were considered important determinants of intake in long-term situations revolved around palatability. First, we considered that the basal palatability of the ration was too low to sustain appropriate levels of intake. Alternatively some items might be so disliked they would drive down total intake or might lead to the intake of a nutritionally imbalanced diet or inadequate vitamin and mineral intakes due to the patterns of diet fortification within the ration. Second, we were concerned that the ration lacked sufficient variety to sustain required levels of intake. The possibility that food monotony would compromise intake and potentially lead to serious weight loss was supported by several studies (Cabanac \& Rabe, 1976; Hashim \& Van Itallie, 1965; Kamen \& Peryam, 1961; Schutz \& Pilgrim, 1958; Siegel \& Pilgrim, 1958). On the other hand, the thorough nutritional surveys conducted during World War II had revealed the absence of nutritional deficiencies among troops when food supplies were adequate (Bean, 1946; Johnson \& Kark, 1946; Webster \& Johnson, 1995; Youmans, 1955). Yet these surveys, as well as more recent observations from the Falkland conflict (McCaig \& Gooderson, 1986), Korea and Vietnam (Popper, Smits, Meiselman, \& Hirsch, 1989), indicated that troops often reported that during combat they ate considerably less than normal. Popper et al. (1989) found that $68 \%$ of the combat veterans they surveyed indicated that on the first day of combat they ate less than usual. It should be noted that the reasons they gave focused on situational variables such as 'engaged in combat,' suggesting insufficient opportunity to eat rather then any shortcoming of the ration.

In the context of these questions it should also be remembered that in the late 1970s the field of human feeding research was relatively undeveloped and the research that existed was sparse and scattered through a number of different journals. There was a solid body of human work on the chemical senses, and food preferences, but the journals Appetite and Food Quality and Preference were still on the horizon and the Society for the Study of Ingestive Behavior did not exist. In sum, when we initially pondered these issues, there was very little systematic data on the control of human feeding behavior, and no adequate models of the complexity of the factors controlling food choice and consumption.

\section{Field and laboratory studies}

In order to answer the questions posed by the new ration, we laid out a two-stage process: a controlled laboratory study with civilians, followed by a field test with military personnel. We will first describe what we observed in the initial ration studies, and our analysis of the factors responsible. We then consider laboratory and field studies of variables that were thought to contribute to our findings.

\section{Methodological considerations}

Before describing these studies several caveats are in order. First, the objective in these ration tests is to evaluate rations, not to conduct controlled human feeding experiments. This means that a new ration being tested has a number of changes in the foods, beverages, packaging, etc. compared to an earlier version; this precludes a balanced design with appropriate control groups. When it is possible, we do have control groups, but this is often not the case. The acceptability and consumption of the rations are regarded as the primary indices of a ration's success or failure. Changes in nutritional status such as body weight, anthropometry, blood nutrients and body fluids are viewed as secondary measures that detail the consequences of any ration shortcoming and simultaneously provide a potential basis for understanding the nature of the ration's weakness such as why insufficient food was consumed. For these reasons great care goes into measuring food intake, and in our first studies a validated methodology for measuring intake in the field was developed for both packaged rations and freshly prepared meals (Hirsch et al., 1985; Wenkam \& Fox, 1989; Wenkam, Fox, Thiele, \& Lichton, 1989). Although not explicitly designed as experiments to test a specific hypothesis about human feeding, these field studies provide a wealth of data about people eating in the real world 
(Meiselman, 1992) that can generate ideas and hypotheses that can be evaluated in a preliminary fashion from the field data and then moved to more controlled situations for resolution. Although military field feeding might not seem the real world to some people, this is the natural condition of eating for soldiers. Some of our observations have been so consistent over twenty years of testing (Kramer et al., in preparation) that we regard the phenomena we discuss as 'real' despite any design weaknesses or confounds in the original ration tests.

This leads to our second caveat. These tests are conducted in the context of military training exercises where the participants are not simply test subjects waiting for their next meal or test. The test groups are intact military units, such as a company of approximately 100 men and women, or smaller units of 30-35 soldiers, such as a platoon, who undergo more intensive testing without random assignment of subjects or identical daily activities.

Third, in many of our studies the control group is fed an entirely different ration that may involve hot meals prepared from fresh ingredients (called A rations) or from canned ingredients (including $\mathrm{B}$ rations and Tray rations). These hot rations are served at a fixed time in a fixed location where people eat their meals in a more social context. In these latter studies differences in the types of ration being tested are necessarily confounded with all the factors associated with being served a hot meal at a scheduled time.

Fourth, in all of these studies the soldiers have a choice about whether to eat at all, whether to eat the ration they received, or to trade the entire meal or parts of it with another soldier. In most natural eating situations, people can choose whether to eat or not, and whether to eat the 'test meal,' if there is one. This is in contrast to most laboratory testing of food items or meals where eating by the subjects is assumed, and the choice not to eat rarely occurs.

Two variables concerning the soldier subjects deserve mention. First, soldiers are under considerable pressure to meet weight standards and approximately $25 \%$ of the soldiers we have tested view going to the field on training exercises as an opportunity to lose weight. Although we have documented this fact (Popper et al., 1987), and try to insure that equivalent numbers of 'dieters' are in the various experimental groups, and often separate out those soldiers who identify themselves as 'trying to lose weight' in our analyses e.g. (Thomas et al., 1995), the interpretation of a particular study can be strained by this fact. Second, most of the data in these studies are from males; when these studies originated in the early 1980s, women soldiers did not serve in the infantry units that we studied. One difficulty of comparing our soldier field data with civilian research data has been that our population is young, male and athletic; many published studies of human eating, especially within the context of obesity, were conducted on females and not always on fit persons.

Finally, the ideal way to conduct a long series of studies on factors controlling intake of military rations would be to keep the ration constant over time while specific aspects or variables were manipulated. This was not possible because the ration kept changing. Natick's ration improvement program tried to continuously improve ration acceptability, so that the ration changed as much as once per year. We discuss some implications of these changes, and some of the lessons learned below, but from a methodological perspective we were dealing with a shifting baseline.

\section{Initial laboratory study_prolonged feeding MRE}

\section{Method}

First, a laboratory study was conducted in collaboration with researchers at the Massachusetts Institute of Technology (MIT) (reference note 1: Scrimshaw et al., 1984; some of these data were previously reported in Hirsch \& Kramer, 1993). Paid student volunteers were divided into two groups that took all of their meals for a 42-day period at the Clinical Research Center at MIT. Twenty, healthy, normal-weight, male subjects began the study in each group, with three dropping out in the MRE group and four in the control group for reasons unrelated to the study. One group received the Meal, Ready-to-Eat (MRE IV) (throughout the text the Roman numeral following the MRE refers to the year this version of the ration was produced) ration as their sole source of food (see Table 1 for a listing of the MRE components).

The other group received a control diet consisting of freshly prepared food that also provided $3600 \mathrm{kcal}$ per day and matched the MRE in macronutrient composition. The control diet was served in a 12-day menu cycle offered in traditional meals. All meals were eaten in a small, pleasant dining room that was open for two-hour periods at 07000900, 1130-1330 and 1700-1900. The MRE group was allowed to exchange ration items, and for this group uneaten items were noted on the feeding records but were available for consumption by other members of the MRE group. In this manner, we tried to mimic the way troops trade and eat these rations in the field. The control group could also consume extra food if at the end of a meal there was uneaten food in the kitchen. It was thus possible for members of both groups to consume more than the $3600 \mathrm{kcal}$ provided. Although we tried to keep the laboratory setting analogous to the field in terms of limitations on food availability, the chance to consume more preferred items and the opportunity to consume additional portions of ration components for the MRE group, we also tried to make the physical and social aspects of actual meals as similar to the control group as possible. In contrast to actual military field feeding, the MRE group had fixed meal times, easy access to hot and cold water for preparing beverages and rehydrating ration components, and a microwave oven for heating food. In addition, dinner plates, eating utensils, bowls and glasses were provided for meals. In sum the eating environment for both groups was much like a simple cafeteria. 
Table 1

Menus in the meal-ready-to-eat (MRE) IV ration

\begin{tabular}{|c|c|c|c|c|c|}
\hline Menu 1 & Menu 2 & Menu 3 & Menu 4 & Menu 5 & Menu 6 \\
\hline $\begin{array}{l}\text { Pork sausage patty, } \\
\text { freeze-dehydrated }\end{array}$ & Ham/chicken loaf & $\begin{array}{l}\text { Beef patty, } \\
\text { freeze-dehydrated }\end{array}$ & $\begin{array}{l}\text { Beef slices with } \\
\text { barbeque sauce }\end{array}$ & Beef stew & Frankfurters \\
\hline Catsup, dehydrated & $\begin{array}{l}\text { Strawberries, } \\
\text { freeze-dehydrated }\end{array}$ & Soup and gravy base & Crackers & Crackers & Catsup, dehydrated \\
\hline Applesauce & Crackers & $\begin{array}{l}\text { Beans with tomato } \\
\text { sauce }\end{array}$ & Peanut butter & Peanut butter & $\begin{array}{l}\text { Beans with tomato } \\
\text { sauce }\end{array}$ \\
\hline Crackers & Peanut butter & Crackers & $\begin{array}{l}\text { Cookie, } \\
\text { chocolate-covered }\end{array}$ & $\begin{array}{l}\text { Fruit mixed, } \\
\text { freeze-dehydrated }\end{array}$ & Crackers \\
\hline Cheese spread & Pineapple nut cake & Cheese spread & $\begin{array}{l}\text { Peaches, } \\
\text { freeze-dehydrated }\end{array}$ & Cherry nut cake & Jelly \\
\hline $\begin{array}{l}\text { Cookies, } \\
\text { chocolate-covered }\end{array}$ & & $\begin{array}{l}\text { Brownies, } \\
\text { chocolate-covered }\end{array}$ & Candy & $\begin{array}{l}\text { Cocoa beverage } \\
\text { powder }\end{array}$ & Candy \\
\hline $\begin{array}{l}\text { Cocoa beverage } \\
\text { powder }\end{array}$ & & Candy & & & $\begin{array}{l}\text { Cocoa beverage } \\
\text { powder }\end{array}$ \\
\hline Menu 7 & Menu 8 & Menu 9 & Menu 10 & Menu 11 & Menu 12 \\
\hline $\begin{array}{l}\text { Turkey, diced with } \\
\text { gravy }\end{array}$ & Beef, diced with gravy & $\begin{array}{l}\text { Cooked beef or } \\
\text { chicken a' la king }\end{array}$ & $\begin{array}{l}\text { Meatballs with } \\
\text { barbecue sauce }\end{array}$ & Ham slices & $\begin{array}{l}\text { Chicken loaf or } \\
\text { ground beef with } \\
\text { spiced sauce }\end{array}$ \\
\hline $\begin{array}{l}\text { Potato patty, } \\
\text { freeze-dehydrated }\end{array}$ & $\begin{array}{l}\text { Beans with tomato } \\
\text { sauce }\end{array}$ & Catsup, dehydrated & $\begin{array}{l}\text { Potato patty, } \\
\text { freeze-dehydrated }\end{array}$ & Crackers & Crackers \\
\hline $\begin{array}{l}\text { Beans with tomato } \\
\text { sauce }\end{array}$ & Crackers & Crackers & Crackers & Cheese spread & Peanut butter \\
\hline Crackers & Cheese spread & $\begin{array}{l}\text { Cheese spread } \\
\text { fruitcake }\end{array}$ & Jelly & $\begin{array}{l}\text { Peaches, } \\
\text { freeze-dehydrated }\end{array}$ & $\begin{array}{l}\text { Strawberries, } \\
\text { freeze-dehydrated }\end{array}$ \\
\hline Maple nut cake & $\begin{array}{l}\text { Brownie, } \\
\text { chocolate-covered }\end{array}$ & $\begin{array}{l}\text { Cocoa beverage } \\
\text { powder }\end{array}$ & Chocolate nut cake & Orange nut roll & $\begin{array}{l}\text { Cookies, } \\
\text { chocolate-covered }\end{array}$ \\
\hline Candy & & & $\begin{array}{l}\text { Cocoa beverage } \\
\text { powder }\end{array}$ & $\begin{array}{l}\text { Cocoa beverage } \\
\text { powder }\end{array}$ & Candy \\
\hline
\end{tabular}

Note: Accessory packet: instant coffee; dry, nondairy cream substitute; granulated sugar; salt; and candy-coated chewing gum. Nonfood components are spoon, matches and toilet paper.

\section{Results}

During the first 2 weeks of the experiment the two groups had comparable levels of caloric intake (Fig. 1). Daily intake for the MRE group began to decline during week 3 and fell from $3380 \mathrm{kcal}$ during week 1 to $3017 \mathrm{kcal}$ during week 6 ( $p<$ $0.01)$, whereas for the control group intake remained stable. Overall, the MRE group ate fewer calories (3149) per day than the control group $(3465 \mathrm{kcal})(p<0.01)$. Hedonic ratings on a 9 -point scale, which were collected at all meals two days each week, did not differ between the two groups when averaged either across all foods eaten or across food categories (entrees, side dishes, desserts and beverages). Hedonic ratings ranged from 6.00 to 6.50 , and entrees averaged 6.45 in the MRE condition and 6.01 in the Control condition. There was a small weight gain in the control group $(0.68 \mathrm{~kg})$ and a small weight loss $(0.69 \mathrm{~kg})$ in the MRE group. Measures of nutritional status, cognitive performance, VO2 max and mood failed to reveal differences between the two dietary conditions. Finally there were no indications of gastrointestinal problems.

\section{Initial field study_prolonged feeding MRE}

The results from the laboratory study contrast sharply to the magnitude of the difference in food intake we observed when troops fed only the MRE for 34 days were compared to troops engaged in similar activities fed freshly prepared foods for breakfast and dinner and an MRE for lunch. In addition, there was also a substantial difference in intake between troops in the field and students in the MIT Clinical Research Center fed the identical version of the MRE (Hirsch et al., 1985; Wenkam \& Fox, 1989; Wenkam et al., 1989).

\section{Method}

The ration test took place at the Pohakuloa Training Area on the Island of Hawaii with two companies from the 25th

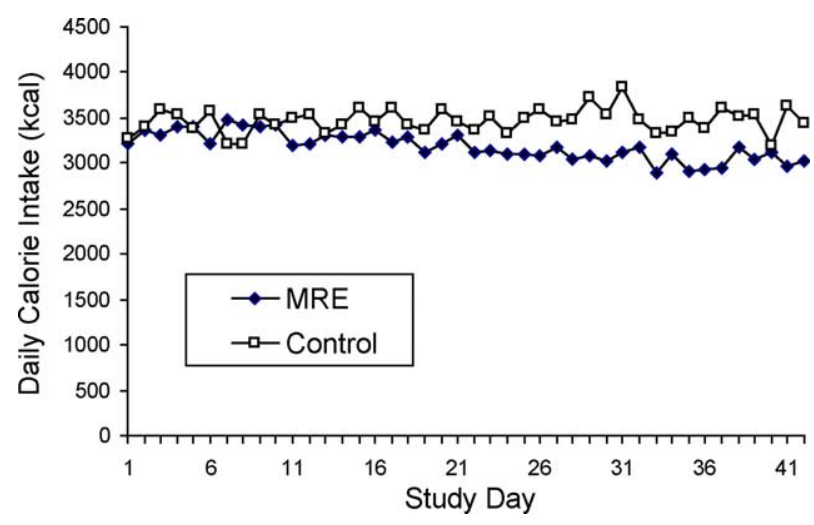

Fig. 1. Mean daily caloric intake for civilians fed three MREs or freshly prepared rations for 42 days. 
Infantry Division participating in a major Division Training Exercise. This training area is remote with virtually no access to commercial food outlets. The terrain is rugged and dry with a fine lava dust covering every surface. The test environment was warm during the day (approximately $29.5^{\circ} \mathrm{C}$ ), cool at night (approximately $15.5^{\circ} \mathrm{C}$ ) and is about $1830 \mathrm{~m}$ above sea level.

The MRE group was provided three MRE meals in the morning. Decisions concerning when and where to eat are usually made by the Company Commander, who is responsible for feeding his troops. Depending on the tasks they were performing or the schedule for that day it was often possible for an individual to eat a snack, a portion of a meal or an entire meal when they chose to.

The control company did not have this element of individual control of their meals. They were served hot, freshly prepared food for breakfast and dinner in a set location at a set time. This context allowed for social interaction at meals as well as the opportunity to obtain additional portions of some items if they were available. Coffee, fruit juice and milk were available whenever control subjects were in the vicinity of the field kitchen. The A-ration meals were prepared from fresh and frozen meats, fruits and vegetables, as well as canned and dehydrated foods. The MRE lunches were eaten at the subject's convenience.

Both groups were allowed to save or trade MRE items for later consumption. Within each company a sub-set of volunteers (27 MRE IV and 30 control diet) underwent more intensive testing on three consecutive days during each week of the study when measures of food and water intake, selected blood and urine variables, and cognitive and psychomotor performance were collected. Only measures of mood, morale, food acceptance and questionnaires about the ration were obtained from the entire company.

\section{Results}

The MRE group consumed $2190 \mathrm{kcal}$ per day and the control group $2950(p<0.01)$. Fig. 2 shows that intake was relatively stable over time in the control group, but declined over time in the MRE group and had not reached asymptote by the end of the study. Both groups lost weight, but the amount of weight loss was much greater in the MRE group (5.8\% of their initial body weight) than in the control group $(2.6 \%)$.

We faced two key questions. First, what accounted for the difference in caloric intake between the two groups in this field test (2190 vs 2950)? Second, why was food intake so much lower (almost $1000 \mathrm{kcal}$ per day) in the soldiers compared to the MIT students fed the identical ration (2190 vs 3149)? Our first impulse was to explain the differences in terms of the characteristics of the food (see Hirsch, 1995 for a detailed review of ration studies that focus on changes in qualities of the food) Fig. 3.

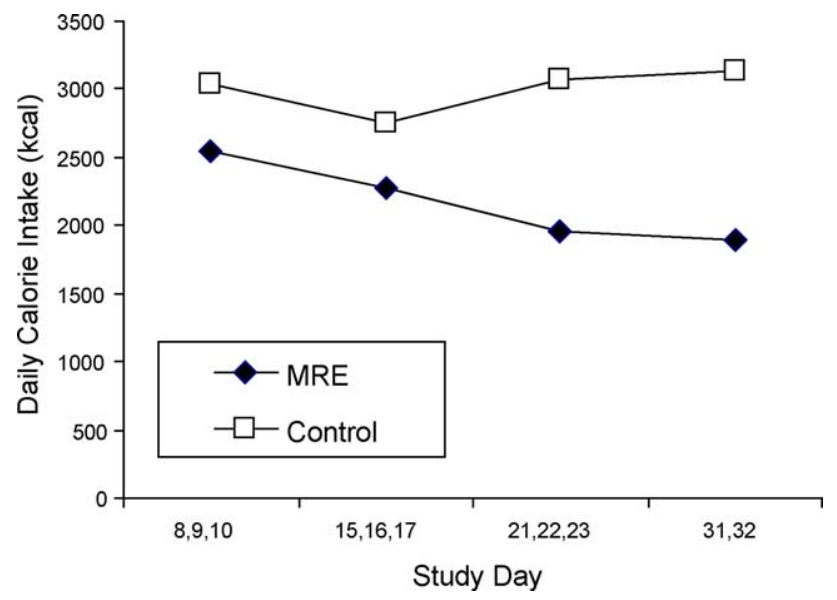

Fig. 2. Mean daily caloric intake for soldiers fed three MREs or two freshly prepared meals and one MRE for 42 days. Note: each point represents the mean intake for the days shown on the $x$-axis.

\section{Attributes of the food}

Food acceptability. There was little evidence to explain intake based on lower food acceptance (Fox, Wenkam, \& Hirsch, 1989; Meiselman, Hirsch, \& Popper, 1988). Troops in both the MRE group and the control group who were eating the MRE for lunch rated all the ration items above 5, the neutral point of the 9-point scale. The troops subsisting on the MRE rated it more highly (7.05) than the control group $6.48(p<0.001)$. At the level of individual items, with one exception, any statistically reliable differences in acceptability between the two groups resulted from higher ratings by the MRE group. The items from the MRE and the freshly prepared control ration foods were grouped into food classes and the ratings for items from comparable food classes were compared over the 5 weeks of the study. The average ratings of the MRE items were significantly higher for the entrees $(\mathrm{MRE}=7.05$, control $=6.48, p<0.01)$, the desserts $(\mathrm{MRE}=6.73$, control $=6.45, p<0.01)$ and the fruits $(\mathrm{MRE}=7.44$, Control $=7.23, p<0.05)$. We do not have an explanation for this pattern.

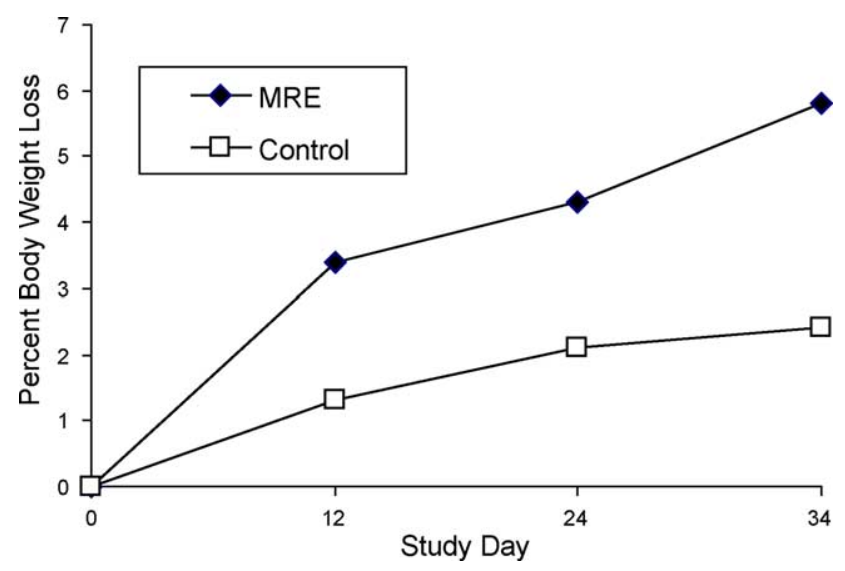

Fig. 3. Mean percentage body weight loss for soldiers fed three MREs or two freshly prepared meals and one MRE for 34 days. 
Monotony. Although both food consumption and acceptance have been used to index the effects of monotonous diets (Cabanac \& Rabe, 1976; Hashim \& Van Itallie, 1965; Kamen \& Peryam, 1960; Schutz and Pilgrim, 1958; Siegel and Pilgrim, 1958), the dissociation between these measures in the field study makes it difficult to assign a clear role to monotony. It is possible that over time troops in the MRE group were simply discarding or trading the items they did not like and consuming only foods they liked. This would leave them with an even smaller universe of foods to consume and this might underlie the lower level of consumption that was observed over time despite the relatively high acceptance ratings.

When a more refined analysis was carried out from other field studies on ration items eaten repetitively (Kramer, Lesher, \& Meiselman, 2001), there was a small but significant increase in average acceptance ratings and in the amount consumed for the items that were repeatedly chosen relative to those items eaten only one time. It is important to note that in this field test most items were consumed only once by a soldier, and frequency of consumption declined monotonically with repetition (most items were eaten once, next twice, and so on). Nevertheless, foods eaten repetitively out of choice are liked more than foods eaten only once or twice. This observation provides support to the hypothesis of discarding disliked items and why average acceptance ratings stayed relatively high despite an over-all decline in food consumption. If monotony plays a role in producing the relatively low levels of energy intake it is better reflected in measures of items discarded rather than hedonic ratings of the items that were actually eaten. In laboratory tests of monotony, participants are asked to repetitively eat items. Under natural conditions, people do not usually eat food that they do not wish to eat, but they may repetitively eat foods that they especially like.

Long-term effects of monotony and of novelty. Given that troops are exposed repeatedly to MREs over the years of their enlistment we might predict a decline in acceptance, choice or intake for those items that remain in the ration. Interestingly, over a period of about 7 years (1985-1992) the MRE underwent essentially no changes and it is possible to compare intake between studies in the groups fed this unchanged version of the MRE. During that time three standard field evaluations were conducted where the MRE was the sole source of food over a 7 to10-day period (Lester et al., 1993; Popper et al., 1987; Hirsch et al., unpublished report). The same standardized methodology (Hirsch et al., 1985) was employed in the three studies, they were conducted in similar environments (two in Hawaii and one in New Mexico during the early fall) and in each case this unchanged version of the MRE was the standard against which a modified ration was compared. Examining intake of the unchanged MRE across time in these three studies revealed a decrease from $2842 \mathrm{kcal}$ per day in the earliest study (Popper et al., 1987) to 1956 (Lester et al., 1993) to $1850 \mathrm{kcal}$ in the most recent field test (Hirsch et al., unpublished report). These observations lend credence to our speculation about the longterm effects of monotony.
Within each of these studies, it is also possible to compare the intake of an MRE version familiar to test participants to one that was more novel (i.e. not as familiar to the test participants. In the Popper et al. (1987) study this MRE was the newest version and intake was approximately $300 \mathrm{kcal}$ more than in the groups receiving earlier versions of the MRE suggesting, in part, a role for novelty. Consistent with this finding, this same version of the MRE was compared to a modified test version of the MRE in the two later studies and in each case soldiers fed the more novel ration consumed 700 (Lester et al., 1993) and 400 (Hirsch et al., unpublished report) more calories per day. This same outcome has also been apparent in later studies where the group receiving a relatively novel 'concept' ration consumed significantly greater amounts than the group receiving a current version of the MRE (Johnson \& Kramer, unpublished report; Baker-Fulco, Kramer, Lesher, Merrill, \& Johnson, 2002). In recent years the MRE has undergone a notable change every year (with at least two new entrees, etc.) and average energy intake is higher than the latter years of the older version (MRE VIII). These observations clearly suggest that regular annual changes in the ration serve to keep intake at an acceptable level. We see some evidence of short-term monotony effects for a ration consumed over single field evaluations, and to some extent, evidence for long-term monotony effects over the lifetime of a ration.

Variety. Is it possible to counteract some of the monotony effects by increasing the variety offered by the ration? Variety within a meal leads to an increase in food intake in humans (e.g. Meiselman, de Graaf, \& Lesher, 2000; Rolls, 2000; see Raynor \& Epstein, 2001 for a recent review), and in experimental animals there is clear evidence that variety across a diet can promote higher levels of intake and obesity (supermarket diet, Sclafani \& Springer, 1976). This suggests that a broader range of food items would enhance military ration intake. In addition, responses to the final questionnaire from the initial extended field study (Hirsch et al., 1985) indicated a strong desire for more variety in the ration, especially in the drinks. Table 2 shows

Table 2

Mean ratings of meal-to-meal variety for seven classes of MRE components (4-pt. Scale, $1=$ variety not enough)

\begin{tabular}{lll}
\hline & $\begin{array}{l}\text { MRE group } \\
(N=82)\end{array}$ & $\begin{array}{l}\text { Control group } \\
(N=73)\end{array}$ \\
\hline Entrees & 2.4 & 2.6 \\
Side dishes & 2.5 & 2.6 \\
Desserts & 2.3 & 2.7 \\
Fruit & 2.5 & 2.7 \\
Supplementary Items & 2.4 & 2.5 \\
(E.G., cheese spread) & & \\
Accessory Items & 3.0 & $2.5^{*}$ \\
(E.G., Pepper, hot sauce) & & \\
Drinks & 3.5 & $3.0^{*}$ \\
\hline
\end{tabular}

$* p<0.01$. 
the responses on a 4-point scale ranging from 1 (Variety Now Enough) to 4 (Should be Much More Variety).

In the intervening 18 years a large number of changes have been introduced to the ration. The individual items in the most recent version better reflect contemporary cuisine and the tastes of young people (see Table 3). The number of food, beverage and snack items in the ration has grown from 35 in MRE IV (produced in 1984) to over 70 in MRE XXII (produced in 2002). Despite this effort to introduce more variety, items that reflect contemporary tastes and tastier, better liked items, a meta-analysis of food intake from ration studies over the past 18 years reveals levels of intake and amounts of uneaten food that are comparable to the initial field test of the MRE (Kramer, et al., in preparation).

While overall intake did not appear to increase as ration variety increased, this increased variety did seem to influence perceptions of variety. Across every food category more recent MRE versions are seen as having 'slightly too little' variety (e.g. Rock, Lesher, Aylward, \& Harrington, 1998) compared to the earlier version described previously which was seen as needing moderately more variety. Also, in reanalyzing data from studies in the early and late 1990s (Lester et al., 1993; Kramer et al., unpublished report), it became evident that soldiers who consumed a larger number of different food items from the ration also had higher overall calorie intakes. As noted earlier, the more recent version of the MRE offers double the number of different foods items available relative to the earlier MRE. In addition, the analyses showed that the average number of different foods actually consumed was also larger (48 versus 25 ) with both the number of different foods consumed and the average daily calorie intakes more consistent (i.e. smaller standard error of the means) in the later study. By giving soldiers a larger universe of foods we may have succeeded in at least minimizing the effects of monotony. These results are consistent with civilian studies finding a positive relationship of dietary variety to diet quality (Drewnowski, Henderson, Driscoll, \& Rolls, 1997). Changes in the ration have also led to improved perceptions of ration quality (e.g. average ratings increased from 7.0 to 7.6 over a seven year period of annual changes in the ration) although we cannot document that this is a consequence of increased variety.

Portion size. Two observations from the first field test pointed to portion size as a potentially important factor in limiting intake in the MRE group (Hirsch et al., 1985). First, on the final questionnaire troops responded in a consistent manner to a question that dealt specifically with the portion sizes of the entrees, side dishes, desserts, fruits, supplementary items and drinks in the MRE. Every category of food was rated below 3.5 on 7 -point scale $(1=$ very dissatisfied to $7=$ very satisfied). Second, the validation work on the intake measures that compared weighed food waste to the subject's estimate of consumption of each component revealed very little waste. Ninety five percent of the time a package was opened for consumption there were no measurable leftovers (Wenkam \& Fox, 1989). This tendency to eat everything in the ration package appears to be analogous to the tendency to 'clean the plate' (Krassner, Brownell, \& Stunkard, 1979), suggesting that larger portions would engender higher levels of intake. These observations, buttressed by laboratory studies that showed larger portion sizes in test meals led to higher levels of caloric intake (Edelman, Engell, Bronstein, \& Hirsch, 1986), encouraged us to recommend that portion sizes be increased selectively in future versions of the MRE.

In 1986, we (Popper et al., 1987) conducted an 11 day test in Hawaii of an experimental version of the MRE that incorporated several changes based on recommendations from our analysis of the prolonged feeding study. Table 4 summarizes the changes that were tested. The entrée portion size was increased from $142 \mathrm{~g} \mathrm{(5} \mathrm{oz.)} \mathrm{to} 227 \mathrm{~g}$ (8 oz.) in seven of the 12 menus. The larger entree group (Improved MRE) lost a significantly lower percentage of their initial body weight (Improved MRE $=2.28 \%$, MRE VII $=2.98 \%$, MRE IV $=3.20 \%, p<0.05$ ) and consumed significantly more calories (Improved MRE $=2842$, MRE VII $=2517$, MRE IV $=2517, p<0.05$ ). More direct evidence for the role of portion size consisted of the observation that higher levels of intake from the larger portions appeared to contribute to the overall levels of intake. The daily level of calories consumed from the entrée was 769 for the Improved MRE group, 650 for the MRE VII group and 510 for the MRE IV group.

Entrée heating. On the final questionnaire of the initial extended feeding study only $18 \%$ of the respondents in the MRE company reported that they always heated their entrée (Hirsch et al., 1985). The method for heating ration components in this version of the MRE consisted of lighting a heating tablet to boil water and then placing the unopened ration package in the hot water. The heating tablets were not packaged with the ration but were provided to troops in the morning when they picked up their meals for the day. On the final questionnaire $52 \%$ of the troops in both companies indicated that they did not have equipment for heating as the reason for not heating their entrees. The other predominant response given for not heating their entrée was there was not enough time. The limited number of studies (Cardello and Maller, 1982; Zellner, Stewart, Rozin, \& Brown, 1988) examining food temperature and food acceptance would suggest that foods 'normally' eaten heated are more acceptable when served warm. This same laboratory phenomenon has been duplicated in our laboratory using six MRE entrees. Using a within subjects design, subjects tasted and rated their liking of each entrée at a cool $\left(10.0^{\circ} \mathrm{C}\right)$, ambient $\left(23.9^{\circ} \mathrm{C}\right)$ and hot $\left(48.9{ }^{\circ} \mathrm{C}\right)$ temperature (Kramer, unpublished observations). Mean hedonic ratings ranged from 4.60 for cool entrees, 5.10 for ambient entrees, and 6.10 for hot entrees. Data from soldiers consuming MREs while engaged in field training are consistent with the laboratory results not only in regard to hedonic ratings but perhaps more importantly, amount consumed. Kramer et al. 
Menus in the meal-ready-to-eat (MRE) XXII ration

\begin{tabular}{|c|c|c|c|c|c|c|c|c|c|c|c|}
\hline Menu 1 & Menu 2 & Menu 3 & Menu 4 & Menu 5 & Menu 6 & Menu 7 & Menu 8 & Menu 9 & Menu 10 & Menu 11 & Menu 12 \\
\hline $\begin{array}{l}\text { Beef steak } \\
\text { w/mushroom } \\
\text { gravy }\end{array}$ & $\begin{array}{l}\text { Jamaican } \\
\text { pork/noodles }\end{array}$ & Beef ravioli & $\begin{array}{l}\text { Country } \\
\text { captain } \\
\text { chicken }\end{array}$ & $\begin{array}{l}\text { Grilled } \\
\text { chicken breast }\end{array}$ & $\begin{array}{l}\text { Oriental } \\
\text { chicken/Thai } \\
\text { sauce }\end{array}$ & $\begin{array}{l}\text { Chicken } \\
\text { w/ salsa }\end{array}$ & $\begin{array}{l}\text { Hamburger } \\
\text { Patty }\end{array}$ & Beef stew & $\begin{array}{l}\text { Chili } \\
\text { w/macaroni }\end{array}$ & $\begin{array}{l}\text { Pasta } \\
\text { w/veg-tomato } \\
\text { (Vegetarian) }\end{array}$ & $\begin{array}{l}\text { Been and rice } \\
\text { burrito } \\
\text { (vegetarian) }\end{array}$ \\
\hline \multirow[t]{2}{*}{$\begin{array}{l}\text { Western style } \\
\text { beans }\end{array}$} & Spiced apples & Potato sticks & $\begin{array}{l}\text { Buttered } \\
\text { noodles }\end{array}$ & $\begin{array}{l}\text { Minestrone } \\
\text { soup }\end{array}$ & White rice & Mexican rice & & & & Fruit & Fruit \\
\hline & & $\begin{array}{l}\text { Fudge } \\
\text { brownie }\end{array}$ & Toaster pastry & $\begin{array}{l}\text { Fudge } \\
\text { brownie }\end{array}$ & $\begin{array}{l}\text { Raisin nut } \\
\text { mix }\end{array}$ & $\begin{array}{l}\text { Shortbread } \\
\text { cookie }\end{array}$ & $\begin{array}{l}\text { Nacho } \\
\text { combos }\end{array}$ & $\begin{array}{l}\mathrm{M} \text { and } \mathrm{M}^{\circledR} \\
\text { cookie }\end{array}$ & Pound cake & Pound cake & Fruit filled bar \\
\hline Peanut butter & $\begin{array}{l}\text { Jalapeno } \\
\text { cheese spread }\end{array}$ & Cheese & Cheese & Jelly & $\begin{array}{l}\text { Jalapeno } \\
\text { cheese spread }\end{array}$ & $\begin{array}{l}\text { Jalapeno } \\
\text { cheese spread }\end{array}$ & Cheese & $\begin{array}{l}\text { Jalapeno } \\
\text { cheese spread }\end{array}$ & Cheese & Peanut butter & Peanut butter \\
\hline \multirow[t]{2}{*}{ Cracker } & $\begin{array}{l}\text { Cracker } \\
\text { (veg. flavor) }\end{array}$ & $\begin{array}{l}\text { Wheat snack } \\
\text { bread }\end{array}$ & Cracker & $\begin{array}{l}\text { Wheat snack } \\
\text { bread }\end{array}$ & $\begin{array}{l}\text { Cracker } \\
\text { (veg. flavor) }\end{array}$ & $\begin{array}{l}\text { Cracker } \\
\text { (veg. flavor) }\end{array}$ & $\begin{array}{l}\text { Wheat snack } \\
\text { bread }\end{array}$ & $\begin{array}{l}\text { Cracker } \\
\text { (veg. flavor) }\end{array}$ & $\begin{array}{l}\text { Wheat snack } \\
\text { bread }\end{array}$ & Cracker & Cracker \\
\hline & & & Candy & Candy & & Candy & BBQ sauce & & & Hard candy & Pound cake \\
\hline $\begin{array}{l}\text { Beef jerky } \\
\text { Bev. base } \\
\text { w/sugar }\end{array}$ & Dairy shake & $\begin{array}{l}\text { Bev. base } \\
\text { w/sugar }\end{array}$ & $\begin{array}{l}\text { Mocha } \\
\text { cappuccino }\end{array}$ & & $\begin{array}{l}\text { French vanilla } \\
\text { cappuccino }\end{array}$ & & $\begin{array}{l}\text { Bev. base } \\
\text { w/sugar }\end{array}$ & Dairy shake & Cocoa & & Picante sauce \\
\hline Red pepper & Hot sauce & Hot sauce & Hot sauce & $\begin{array}{l}\text { Seasoning } \\
\text { packet }\end{array}$ & Hot sauce & Hot sauce & Hot sauce & Hot sauce & Red pepper & $\begin{array}{l}\text { Seasoning } \\
\text { packet }\end{array}$ & $\begin{array}{l}\text { Seasoning } \\
\text { packet }\end{array}$ \\
\hline Spoon & Spoon & Spoon & Spoon & Spoon & Spoon & Spoon & Spoon & Spoon & Spoon & Spoon & Spoon \\
\hline ACC Pkt-B & ACC Pkt-A & ACC Pkt-A & ACC Pkt-A & ACC Pkt-D & ACC Pkt-E & ACC Pkt-C & ACC Pkt-C & ACC Pkt-A & ACC Pkt-B & ACC Pkt-D & ACC Pkt-D \\
\hline FRH & FRH & FRH & FRH & FRH & FRH & FRH & FRH & FRH & FRH & FRH & FRH \\
\hline Menu 13 & Menu 14 & Menu 15 & Menu 16 & Menu 17 & Menu 18 & Menu 19 & Menu 20 & Menu 21 & Menu 22 & Menu 23 & Menu 24 \\
\hline $\begin{array}{l}\text { Cheese } \\
\text { tortellini } \\
\text { (vegetarian) }\end{array}$ & $\begin{array}{l}\text { Pasta } \\
\text { w/vegetable } \\
\text { alfredo sce } \\
\text { (vegetarian) }\end{array}$ & $\begin{array}{l}\text { Beef } \\
\text { enchiladas }\end{array}$ & $\begin{array}{l}\text { Chicken } \\
\text { w/noodles }\end{array}$ & $\begin{array}{l}\text { Beef } \\
\text { teriyaki }\end{array}$ & $\begin{array}{l}\text { Turkey breast } \\
\text { pot/gravy }\end{array}$ & $\begin{array}{l}\text { Beef } \\
\text { w/mushrooms }\end{array}$ & $\begin{array}{l}\text { Spaghetti } \\
\text { w/meat sauce }\end{array}$ & $\begin{array}{l}\text { Chicken } \\
\text { tetrazzini }\end{array}$ & Jambalaya & $\begin{array}{l}\text { Chicken } \\
\text { w/cavetelli }\end{array}$ & $\begin{array}{l}\text { Meatloaf } \\
\text { w/gravy }\end{array}$ \\
\hline Applesauce & Fruit & Mexican rice & $\begin{array}{l}\text { Raspberry } \\
\text { applesauce }\end{array}$ & $\begin{array}{l}\text { Chow mein } \\
\text { noodles }\end{array}$ & $\begin{array}{l}\text { Combos } \\
\text { cheddar }\end{array}$ & $\begin{array}{l}\text { Yellow and } \\
\text { wild rice pilaf }\end{array}$ & & & & & $\begin{array}{l}\text { Mashed } \\
\text { potatoes }\end{array}$ \\
\hline Pound cake & $\begin{array}{l}\text { Dry roasted } \\
\text { nuts }\end{array}$ & $\begin{array}{l}\text { Chocolate } \\
\text { chip cookies }\end{array}$ & Fig bar & $\begin{array}{l}\text { Cheese and } \\
\text { p'nut butter } \\
\text { cracker }\end{array}$ & & $\begin{array}{l}\text { Oatmeal } \\
\text { cookie }\end{array}$ & $\begin{array}{l}\text { Toasted p'nut } \\
\text { butter cracker }\end{array}$ & Pound cake & $\begin{array}{l}\text { Chocolate } \\
\text { covered } \\
\text { cookie }\end{array}$ & Pound cake & Toaster pastry \\
\hline Peanut butter & Peanut butter & $\begin{array}{l}\text { Jalapeno } \\
\text { cheese spread }\end{array}$ & Cheese spread & Jam & Peanut butter & Jam & Cheese spread & Jelly & Cheese spread & Peanut butter & Jelly \\
\hline Cracker & Cracker & $\begin{array}{l}\text { Cracker } \\
\text { (veg. flavor) }\end{array}$ & $\begin{array}{l}\text { Cracker } \\
\text { (veg. flavor) }\end{array}$ & $\begin{array}{l}\text { Wheat snack } \\
\text { bread }\end{array}$ & Cracker & Cracker & $\begin{array}{l}\text { Wheat snack } \\
\text { bread }\end{array}$ & Cracker & $\begin{array}{l}\text { Wheat snack } \\
\text { bread }\end{array}$ & $\begin{array}{l}\text { Wheat snack } \\
\text { bread }\end{array}$ & $\begin{array}{l}\text { Cracker } \\
\text { (veg. flavor) }\end{array}$ \\
\hline \multirow[t]{2}{*}{ Hard candy } & Pound cake & & Candy & Candy & $\begin{array}{l}\text { Chocolate } \\
\text { sports bar }\end{array}$ & & Hard candy & & Candy & & \\
\hline & & $\begin{array}{l}\text { Bev. Base } \\
\text { w/sugar }\end{array}$ & Cocoa & $\begin{array}{l}\text { Bev. base } \\
\text { w/sugar }\end{array}$ & $\begin{array}{l}\text { Bev. base } \\
\text { w/sugar }\end{array}$ & Cocoa & Dairy shake & Dairy shake & $\begin{array}{l}\text { Bev. base } \\
\text { w/sugar }\end{array}$ & $\begin{array}{l}\text { Bev. base } \\
\text { w/sugar }\end{array}$ & Cocoa \\
\hline $\begin{array}{l}\text { Seasoning } \\
\text { packet }\end{array}$ & $\begin{array}{l}\text { Seasoning } \\
\text { packet }\end{array}$ & Hot sauce & Hot sauce & Red pepper & Hot sauce & Hot sauce & Hot sauce & Hot sauce & Hot sauce & Hot sauce & Red pepper \\
\hline Spoon & Spoon & Spoon & Spoon & Spoon & Spoon & Spoon & Spoon & Spoon & Spoon & Spoon & Spoon \\
\hline ACC Pkt-D & ACC Pkt-D & ACC Pkt-A & ACC Pkt-A & ACC Pkt-E & ACC Pkt-A & ACC Pkt-A & ACC Pkt-A & ACC Pkt-E & ACC Pkt-A & ACC Pkt-A & ACC Pkt-B \\
\hline FRH & FRH & FRH & FRH & FRH & FRH & FRH & FRH & FRH & FRH & FRH & FRH \\
\hline
\end{tabular}

Case A = menus 1-12, case B = menus 13-24. Accessory packet A: Coffee, cream substitute, sugar, salt, chewing gum, matches, toilet tissue, towelette. Accessory packet B: coffee, cream substitute, sugar, salt, chewing gum, matches, toilet tissue, towelette, candy (vanilla caramels or tootsie rolls), ground red pepper. Accessory packet C: Lemon tea w/sugar, salt, chewing gum, matches, toilet tissue, towelette. Accessory packet D: lemon tea w/sugar, apple cider, salt, chewing gum, matches, toilet tissue, towelette, seasoning packet (salt-free). Accessory packet E: tea bag, cream substitute, sugar, chewing gum, matches, toilet tissue, towelette. 
Table 4

Features of three versions of the MRE tested in 1986

\begin{tabular}{ll}
\hline Improved MRE & MRE VII \\
\hline 12 menus: 9 new and 2 reformulated entrees & $\begin{array}{l}12 \text { menus, same entrees as MRE V but 8-oz portions for } 7 \\
\text { menus }\end{array}$ \\
$\begin{array}{l}\text { 8-oz portions for } 7 \text { entrees } \\
2 \text { Breakfast entrees }\end{array}$ & $\begin{array}{l}\text { Fruit-flavored beverages in all menus } \\
\text { Hot pepper sauce in 3 menus }\end{array}$ \\
$\begin{array}{l}\text { Fruit-flavored beverages in all menus } \\
\text { Wet pack fruits }\end{array}$ & \\
Hot pepper sauce in 4 menus; commercial candy & \\
\hline
\end{tabular}

Source: adapted from Popper et al. (1987).

(unpublished report) observed that when soldiers heated their entrees they gave them an overall hedonic rating of 7.60 and consumed an average of $220 \mathrm{cal}$ of that entrée. When they did not heat, average entrée ratings were significantly lower $(7.20, p<0.05)$ and fewer calories $(166, p<0.01)$ were consumed.

Beverages. Beverages play two important roles in a ration system to support adequate nutrient intake (Engell, 1995). Their primary role is to provide a source of calories. Secondarily, adequate beverage consumption is critical for maintaining fluid balance. If fluid intake is insufficient, the resulting hypohydration leads to a voluntary reduction in food intake. In MRE IV coffee and cocoa were the only beverages provided. Troops obtained about $178 \mathrm{kcal}$ per day from the cocoa, the one caloric beverage provided. The troops did perceive the limited number of beverages provided in MRE IV as a serious shortcoming. On the final questionnaire, they listed a Kool-Aid type beverage as the drink they would most like added to the ration. Despite this deficiency, the limited number of beverages did not produce levels of fluid intake that were low enough to lead to hypohydration. The MRE group consumed less fluid per day than the control group (2657 vs. $3123 \mathrm{ml}$ ), but their urine volumes and osmolalities were well within the normal range (Lichton, Miyamura, \& McNutt, 1988). Despite field beverage intakes that were relatively low and the consumption of less than $200 \mathrm{kcal}$ per day from this ration component it does not appear that the difference in MRE IV energy intake in the field and at MIT can be accounted for in terms of beverage intake. However the data were a clear indication that provision of beverages could be modified to improve ration consumption.

Subsequent versions of the ration introduced a variety of new caloric beverages including sweetened fruit-flavored beverage bases, tea, apple cider, and dairy shakes. In reviewing these ration changes from 1985 through 1993, Engell (1995) concluded that as the number of caloric beverages in the MRE increased so did their consumption resulting in higher caloric and fluid intake. Calories from this source contributed to over-all increases in energy intake rising as high as $539 \mathrm{kcal}$, or approximately $20 \%$ of daily energy intake, when energy dense dairy shakes were employed as ration beverages (Lester et al., 1993). These new beverages also had a positive influence on fluid balance. For example, Popper et al. (1987) found that over the course of an 11-day field test using daily measures of urine specific gravity as an index of hydration status, the Improved MRE group and the MRE VII group, who were provided with sweetened, flavored beverages, had a lower incidence of individuals with values above 1.030. This value is often considered a value indicative of the body's effort to concentrate urine, if not frank hypohydration (Francesconi et al., 1987).

Time of day and meal type. Individual rations, such as the MRE, are not designed to have a set of meal specific menus (i.e. breakfast menu, dinner menu). In the prolonged feeding study (Hirsch et al., 1985) the troops ranked the inclusion of breakfast items as the second most important change to improve the ration. Many foods are seen as appropriate for only certain meals and reflecting such findings, earlier versions of the MRE did attempt to incorporate some 'breakfast' menus (e.g. a meal with an omelet as the entrée). However, these menus proved relatively less acceptable, and items such as eggs presented technological challenges that continue today. Perhaps of greater significance is that having meal specific menus-while attractive in conceptdid not seem to enhance consumption. Subsequent controlled meal studies appear to support these conclusions. When civilian subjects in a laboratory study were asked to rate the appropriateness of a set of foods for breakfast and lunch large differences were found and when given a choice of foods for a meal, rated appropriateness was related to food choice (Kramer, Rock, \& Engell, 1992). Nonetheless when subjects - based on their own ratings-were given a meal composed of foods considered inappropriate for that time of day neither food intake nor food acceptance appeared to be adversely affected. A broader discussion of food appropriateness and its relation to military field feeding can be found in Schutz (1995).

\section{Summary—effects of ration changes}

We have described the pattern of ration underconsumption uncovered in early prolonged feeding tests, analyzed the causes of the underconsumption, and conducted laboratory and field experiments on the characteristics of 
Table 5

Summary of findings in MRE studies

\begin{tabular}{|c|c|}
\hline Acceptance & $\begin{array}{l}\text { Lower when fed in a cafeteria than in a field } \\
\text { setting. Improved over time with newer } \\
\text { version rated higher }\end{array}$ \\
\hline Consumption & $\begin{array}{l}\text { Higher in a cafeteria than in a field setting } \\
\text { Entire food item typically eaten once the } \\
\text { package is opened (i.e. 'clean the plate') }\end{array}$ \\
\hline Novelty & $\begin{array}{l}\text { A relatively novel MRE version was } \\
\text { consumed significantly more than a current } \\
\text { version }\end{array}$ \\
\hline $\begin{array}{l}\text { Monotony/repeated } \\
\text { serving }\end{array}$ & $\begin{array}{l}\text { Small but significant increase in acceptance } \\
\text { ratings and amount consumed for foods } \\
\text { repeatedly chosen relative to those eaten only } \\
\text { one time }\end{array}$ \\
\hline Long-term monotony & $\begin{array}{l}\text { When the MRE underwent essentially no } \\
\text { changes for } 7 \text { years, daily energy intake } \\
\text { declined over time }\end{array}$ \\
\hline Variety & $\begin{array}{l}\text { Soldiers who consumed a larger number of } \\
\text { different MRE items had higher calorie } \\
\text { intakes, but over time soldiers continue to } \\
\text { request greater variety }\end{array}$ \\
\hline Portion sizes & $\begin{array}{l}\text { Larger portion sizes led to higher intake of the } \\
\text { item and overall intake }\end{array}$ \\
\hline Heating food & $\begin{array}{l}\text { For both civilian laboratory and military data, } \\
\text { when food was appropriately served hot it is } \\
\text { rated more highly and consumed in greater } \\
\text { amount }\end{array}$ \\
\hline Beverages & $\begin{array}{l}\text { Increased beverage consumption produced } \\
\text { higher overall intakes and lower dehydration }\end{array}$ \\
\hline $\begin{array}{l}\text { Time of day and } \\
\text { meal effects }\end{array}$ & $\begin{array}{l}\text { Clear difference in stated appropriateness and } \\
\text { foods chosen at different mealtimes but no } \\
\text { clear impact on actual intake/acceptance }\end{array}$ \\
\hline
\end{tabular}

the food. The results of this work are summarized in Table 5.

In both short-term laboratory experiments, where key variables were isolated, and in initial field tests that compared an old version of a ration to a modified experimental version, the results most often revealed that the 'improvements' led to higher intake and better acceptance in both the laboratory and the field. However, over time troops may encounter these same rations several times a year for successive years on field training exercises, and the version of the ration which initially looked like a genuine improvement becomes stale and both food intake and acceptance decline. This basal level of intake is generally sufficient to sustain health and performance in the short term, but over extended periods (months) intake might become too low and compromise both. In fact this is what we observed in 7-10 day tests during a period when the ration had undergone almost no change (see monotony section). These observations lead us to speculate that regular ration changes are required to sustain this basal level of acceptance and intake and in their absence troops provided with the identical rations year after year would display inadequate levels of energy intake in the field. Ration changes are probably critical to sustain intake but over the long term they will not improve it.

\section{Revisiting field versus cafeteria/lab}

While we continued to pursue the food attributes in order to improve the ration, we also became increasingly convinced that food attributes alone are not driving the outcome of our ration testing. We conducted a new study of MRE consumption in the field versus a controlled cafeteria setting (reported in Hirsch \& Kramer, 1993). Two similar groups of Army soldiers were fed an identical ration in a cafeteria setting or in the field. Activity levels, age and body size were also similar for the two groups. Subjects in the cafeteria group ate all meals for a 5 day period at fixed times $(0800,1200,1700)$ in a cafeteria setting with tables and chairs. The meals were heated and prepared for the participants by study personnel. At any given meal, all subjects were served the same food items (i.e. 1 of the 12 menus available in the ration). Rations were taken out of the package, re-hydrated, heated as appropriate and served restaurant style on individual trays, using utensils, plates, bowls and cups. Serving sizes were identical to those provided by the foods as packaged, with the exception of cold beverages that were served in $200 \mathrm{ml}$ rather than $355 \mathrm{ml}$ portions. Subjects were free to request additional portions of any item, and/or take items for between meal snacks. Water was available during the meal, and the soldiers were permitted to drink water between meals. All food and drinks on the trays were weighed before and after eating to determine intake.

Subjects in the field group were issued three MRE's per day with no means of heating items. No effort was made to control which meals were chosen, since this represents the typical use of the MRE, and subjects were free to trade or give away items.

Average intakes for the cafeteria and field groups were 3838 and $2875 \mathrm{kcal}$, respectively. The group difference in energy intake was not due to the cafeteria subjects taking between meal snacks, as little was actually eaten between meals (69.3 kcal per day). Not only did the intake pattern match the previous study, but the pattern of acceptance ratings was also duplicated. Average acceptance for the cafeteria group was 6.30 and for the field group 6.90. Just as in the first field ration study, the ration that scored higher was consumed at a lower level, and the ration that scored lower was consumed at a higher level.

The results of this experiment confirm that caloric intake is markedly higher and acceptance lower when the identical food is consumed in a cafeteria setting relative to a field environment. The cafeteria feeding environment in this study differed from that in the MIT study in at least two major ways. First, the ration was prepared and served on a plate to the participants. Second, additional food was readily available and subjects were asked if they wanted more. However, substantial differences in food intake and acceptance were again observed when the identical food was fed in two different environments. Acceptance differences in different eating locations have recently been 
documented in other studies (Edwards, Meiselman, Edwards, \& Lesher, 2003; Meiselman, Johnson, Reeve, \& Crouch, 2000).

Although the duration of the study was only 3 full days, our previous observations with MIT students and soldiers in the field, suggest that the magnitude of this difference in intake would hold up or even get larger over an extended time period. In fact, the level of intake by the field group was virtually identical to that seen in a longer-term field study employing the same version of the ration (Popper et al., 1987). In the laboratory setting with MIT students, energy intake decreased approximately $300 \mathrm{kcal}$ from the first to the sixth week, whereas in the field intake declined almost $900 \mathrm{kcal}$ over the 34 days of testing (Hirsch et al., 1985). It is striking that intakes over $2900 \mathrm{kcal}$ were never obtained with MREs under field conditions, while intakes over $2900 \mathrm{kcal}$ were always obtained in these studies when MREs or fresh food was served in a more fixed environment.

\section{Situational and contextual variables}

We have learned that palatable food that requires effort to prepare and consume in an austere or even unpleasant environment is not consumed in sufficient quantity to maintain body weight over extended time periods. Beyond that, we have learned some important lessons which we feel are applicable beyond the military feeding situation. First, our initial emphasis on the characteristics of the food had to be balanced with many important situational factors, which are still insufficiently considered in human nutrition research. Second, we came to question whether variables that had powerful effects on human food intake in shortterm laboratory studies exerted similar effects on long-term intake. Third, we believe that these concerns could readily be extended to the obesity epidemic where situational factors such as effort might be as important or more important than food attributes.

We have explored many dimensions of the food and believe that within the limits of current technology there is little more to be gained in terms of solving the Army's underconsumption problem by modifying the nature of the ration any further. Conversely we have adduced considerable evidence for the importance of ration improvements in maintaining basal levels of acceptance and intake for troops periodically exposed to these rations during training and deployments over a span of years. If correct this conclusion has many implications for military feeding as well as our broader understanding of human food intake.

The major issue we are left with concerns specifying the aspects of the feeding environment that contribute to these substantial differences in energy intake. Relative to modifying the food it is far harder to abstract the critical features of the environment that might underlie the differences in food intake and create laboratory analogues that allow systematic study. The potential variables are myriad. The effort associated with consuming a meal in the field and the nature of the social environment are two contextual variables that have been examined in both environments, and the parallel effects they exert on food intake underscores their potential importance for an understanding of food intake in the real world as well as providing a way to improve military field feeding. Previous reviews (Engell, 1995; Hirsch \& Kramer, 1993; Kramer, 1995), have attempted to relate field observations from military feeding studies to laboratory research with animals and humans. Other reviews of situational variables have also drawn on this work (Bell \& Meiselman, 1995; Meiselman, 1996).

Time and energy must be expended to obtain food and water. There is a growing literature showing that human food choice and intake are quite sensitive to the physical and monetary costs involved in eating in short term laboratory meals. We have previously detailed the numerous tasks a soldier in the field must complete to prepare, consume and clean-up from a meal of operational rations like the MRE (Hirsch \& Kramer, 1993). These constraints on feeding play a major role in limiting intake in soldiers in the field and whatever makes eating easier, and less time consuming will lead to higher levels of caloric intake. Further efforts to improve the eating situation will need to be balanced against military tradition and against sound reasons of military logistics and military strategy.

\section{Acknowledgements}

This review contributes to a second Special Section on US Army Research, originally conceived by H.L. Meiselman, F.M. Kramer, J. Dwyer, and D. Booth, and guest-edited by P. Pliner, H.L. Meiselman, and F.M. Kramer. The first Special Section on US Army Research appeared in 2003, Volume 40, Number 3.

\section{References}

Baker-Fulco, C. J., Kramer, F. M., Lesher, L. L., Merrill, E. P., \& Johnson, J. (2002). Dietary intakes of female and male combat support hospital personnel subsisting on meal-focused or standard versions of the meal, ready-to-eat. Technical Report USARIEM/T02-23.

Bean, W. B. (1946). Nutrition survey of American troops in the Pacific. Nutrition Reviews, 6, 345-363.

Bell, R., \& Meiselman, H. L. (1995). The role of eating environments in determining food choice. In D. Marshall (Ed.), Food choice and the consumer (pp. 292-310). Glasgow: Blackie Academic and Professional, 292-310.

Cabanac, M., \& Rabe, E. F. (1976). Influence of a monotonous diet on body weight regulation in humans. Physiology and Behavior, 17, 675-678.

Cardello, A. V., \& Maller, O. (1982). Acceptability of water, selected beverages and foods as a function of serving temperature. Journal of Food Science, 47, 1549-1552. 
Drewnowski, A., Henderson, S. A., Driscoll, A., \& Rolls, B. J. (1997). The dietary variety score: assessing diet quality in healthy young and older adults. Journal of the American Dietetic Association, 97, 266-271.

Edelman, B., Engell, D., Bronstein, P., \& Hirsch, E. (1986). Environmental effects on the intake of overweight and normal-weight men. Appetite, 7 , 71-83.

Edwards, J. S. A., Meiselman, H. L., Edwards, A., \& Lesher, L. (2003). The influence of eating location on the acceptability of identically prepared foods. Food Quality and Preference, 14, 647-652.

Engell, D. (1995). Effects of beverage consumption and hydration status on caloric intake. In B. M. Marriott (Ed.), Not eating enough (pp. 217237). Washington, DC: National Academy Press, 217-237.

Fox, M., Wenkam, N., \& Hirsch, E. (1989). Acceptability studies of military ration. Journal of Foodservice Systems, 5, 189-197.

Francesconi, R. P., Hubbard, R. W., Szlyk, P. C., Schnakenberg, D., Carlson, D., Leva, N., Sils, I., Hubbard, L., Pease, V., Young, J., \& Moore, D. (1987). Urinary and hematologic indexes of hypohydration. Journal of Applied Physiology, 62, 1271-1276.

Hashim, S. A., \& Van Itallie, T. B. (1965). Studies in normal and obese subjects with a monitored food dispensing device. Annals of the New York Academy of Sciences, 131, 654-661.

Hirsch, E. (1995). The effects of ration modifications on energy intake, body weight change and food acceptance. In B. M. Marriott (Ed.), Not eating enough (pp. 151-173). Washington, DC: National Academy Press, 151-173. 173.

Hirsch, E., \& Kramer, M. F. (1993). Situational influences on food intake. In B. M. Marriott (Ed.), Nutritional needs in hot environments (pp. 215243). Washington, DC: National Academy Press, 215-243.

Hirsch, E., Meiselman, H. L., Popper, R. D., Smits, G., Jezior, B., Lichton, I., Wenkam, N., Burt, J., Fox, M., McNutt, S., Thiele, M. N., \& Dirige, O. (1985). The effects of prolonged feeding Meal, Ready-To-Eat (MRE) operational rations. Technical Report Natick TR-85/035. U.S. Army Natick Research, Development and Engineering Center, Natick: MA.

Johnson, R. E., \& Kark, R. M. (1946). Feeding problems in man as related to the environment. An analysis of United States and Canadian army ration trials, 1941-1946, Chicago., Quartermaster Food and Container Institute for the Armed Forces, Research and Development Branch, Office of the Quartermaster General.

Kamen, J. A., \& Peryam (1961). Acceptability of repetitive diets. Food Technology, $X V, 173-177$.

Kramer, F. M. (1995). The physical eating situation. In B. M. Marriott (Ed.), Not eating enough (pp. 319-339). Washington, DC: National Academy Press, 319-339.

Kramer, F. M., Merrill, E., Dichiara, A., Lesher, L. L., Meiselman, H. L., \& Hirsch, E. Stable long term patterns of intake by soldiers fed field rations - a metanalysis, in preparation.

Kramer, F. M., Lesher, L. L., \& Meiselman, H. L. (2001). Monotony and choice: Repeated serving of the same item to soldiers under field conditions. Appetite, 36, 239-240.

Kramer, F. M., Rock, K., \& Engell, D. (1992). Effects of time of day and appropriateness on food intake and hedonic ratings of morning and midday meals. Appetite, 14, 1-13.

Krassner, H. A., Brownell, K. D., \& Stunkard, A. J. (1979). Cleaning the plate: food left by overweight and normal weight persons. Behavioral Research and Therapy, 17, 155-156.

Lester, L. S., Lesher, L. L., Salamon, M., Engell, D. B., Dewey, S. L., Ward, J. C., Thomas, C., \& Kalick, J. (1993). Nutritional and hedonic consequences on consuming the Meal, Ready-to-Eat (MRE) VIII or the Soldier Enhancement Program (SEP) MRE. Technical Report TR93/015. U.S. Army Natick Research, Development and Engineering Center, Natick: MA.

Lichton, I. J., Miyamura, J. B., \& McNutt, S. (1988). Nutritional evaluation of soldiers subsisting on meal, ready-to eat operational rations for an extended period. American Journal of Clinical Nutrition, $48,30-37$.
McCaig, R. H., \& Gooderson, C. Y. (1986). Ergonomic and physiological aspects of military operations in a cold wet climate. Ergonomics, 29, 849-857.

Meiselman, H. L. (1992). Methodology and theory in human eating research. Appetite, 19, 49-55.

Meiselman (1996). The contextual basis for food acceptance, food choice and food intake: the food, the situation and the individual. In H. L. Meiselman, \& H. J. H. MacFie (Eds.), Food choice, acceptance and consumption (pp. 239-263). Blackie Academic and Professional, 239-263.

Meiselman, H. L., de Graaf, C., \& Lesher, L. L. (2000). The effects of variety and monotony on food acceptance and intake at a midday meal. Physiology and Behavior, 70, 119-125.

Meiselman, H. L., Hirsch, E. S., \& Popper, R. D. (1988). Sensory, hedonic and situational factors in food acceptance and consumption. In D. M. H. Thomson (Ed.), Food acceptability (pp. 77-87). London: Elsevier, 77-87.

Meiselman, H. L., Johnson, J. L., Reeve, W., \& Crouch, J. E. (2000). Demonstration of the influence of the eating environment on food acceptance. Appetite, 35, 231-237.

Mokdad, A. H., Bowman, B. A., Ford, E. S., Vinicor, F., Marks, J. S., \& Koplan, J. P. (2001). The continuing epidemics of obesity and diabetes in the United States. Journal of the American Medical Association, 286, 1195-1200.

Popper, R., Hirsch, E., Lesher, L., Engell, D., Jezior, B., Bell, B., \& Matthew, W. T. (1987). Field evaluation of improved MRE, MRE VII and MRE IV. Technical Report Natick TR-87/027. U.S. Army Natick Research, Development and Engineering Center, Natick: MA.

Popper, R., Smits, G., Meiselman, H. L., \& Hirsch, E. (1989). Eating in combat: a survey of U.S. Marines. Military Medicine, 154, 619-623.

Raynor, H. A., \& Epstein, L. H. (2001). Dietary variety, energy regulation and obesity. Psychological Bulletin, 127, 325-341.

Rock, K. L., Lesher, L. L., Aylward, J., \& Harrington, M. S. (1998). Field acceptance and nutritional intake of the meal, ready-to-eat and heat and serve ration. Technical Report Natick TR-98/022. U.S. Army Natick Research, Development and Engineering Center, Natick: MA.

Rolls, B. J. (2000). Sensory-specific satiety and variety in the meal. In H. L. Meiselman (Ed.), (pp. 107-116). Gaithersburg, MD: Aspen Publishers, 107-116.

Schutz, H. G. (1995). Eating situations, food appropriateness, and consumption. In B. M. Marriott (Ed.), Not eating enough (pp. 341360). Washington, DC: National Academy Press, 341-360.

Schutz, H. G., \& Pilgrim, F. J. (1958). A field study of food monotony. Psychological Reports, 4, 559-565.

Sclafani, A., \& Springer, D. (1976). Dietary obesity in adult rats: Similarities to hypothalamic obesity and human obesity syndromes. Physiology and Behavior, 17, 461-471.

Siegel, P. S., \& Pilgrim, F. J. (1958). The effect of monotony on the acceptance of food. American Journal of Psychology, 71, 756-759.

Thomas, C. D., Friedl, K. E., Mayes, M. Z., Mutter, S. H., Moore, R. J. Jezior, D. A., Baker-Fulco, C. J., Marchitelli, L. J., Tulley, \& Askew, W. E. (1995). Nutrient intakes and nutritional status of soldiers consuming the meal, ready-to-eat (MRE XII) during a 30-day field training exercise. Technical Report No. T95-6. U.S. Army Research Institute of Environmental Medicine, Natick, MA.

Webster, E. C., \& Johnson, F. H. Questionnaire of wounded soldiers. Part II. Data on rations in combat and behind the lines. Report No. C6162 to the Associate Committee Army Medical Research, National research Council Canada.

Wenkam, N. S., \& Fox, M. (1989). Validity of self-estimated and weighed dietary data for assessment of military rations. Journal of the American Dietetic Association, 89, 203-208.

Wenkam, N. S., Fox, M., Thiele, M. N., \& Lichton, I. J. (1989). Energy and nutrient intakes of soldiers consuming MRE operational rations: Physiological correlates. Journal of the American Dietetic Association, 89, 407-409. 
Youmans, J. B. (1955). Malnutrition and deficiency diseases. In J. B. Coates, \& E. C. Hoff (Eds.), Preventive medicine in World War II. Washington, DC: Office of the Surgeon General, Department of the Army.

Zellner, D. A., Stewart, W. F., Rozin, P., \& Brown, J. M. (1988). Effect of temperature and expectations on liking for beverages. Physiology and Behavior, 44, 61-68.

\section{Reference Note}

1. Scrimshaw, N. S., Storch, K. J., Hirsch, E., Udall, J. N., Besrat, A., Oliver, W., \& Rand, W. (1984). The evaluation of the tolerability and nutritional value of a currently used combat ration. Final Report to the U.S. Army Natick Research and Development Center, Contract \# DAAK 60-83-C-0017. 